\title{
Isolation of cellulolytic bacteria, including actinomycetes, from coffee exocarps in coffee-producing areas in Vietnam
}

\author{
Han B. Bui
}

Received: 21 February 2013/Accepted: 25 December 2013/Published online: 20 February 2014

(c) The Author(s) 2014. This article is published with open access at Springerlink.com

\begin{abstract}
Background Microorganisms have been used to decompose cellulolytic waste in agriculture for the past many years. However, much of the cellulosic waste including coffee exocarps which are wastes from raw coffee process in Vietnam is often disposed of by biomass burning and discharged into the environment in developing countries, thus causing considerable environmental pollution. Besides, these organic wastes decompose slowly when they are used to produce compost in ordinary conditions. Therefore, using microorganisms to manufacture natural compost from coffee exocarps is considered a useful and environmentally sound alternative.

Results In the course of screening for cellulose-degrading bacteria and actinomycetes, 38 bacterial strains and 18 actinomycetes strains were isolated from 15 coffee exocarp samples in coffee-producing areas in Vietnam. The isolates grew with cellulose as the sole sources of carbon and energy. The results of cellulolytic activity determinations were that 13 bacteria $(>34 \%)$ and 10 actinomycetes (>56\%) showed enzymatic degradation of cellulose. The isolated strains were identified as belonging to members of the Genus Streptomyces, Actinomycetes, Clostridium and Bacillus. Cellulose-degrading ability of the isolated microorganism strains was mostly $96 \%$ with filter paper; however, for coffee exocarps, it was considerably lower, only about $37 \%$ of the cellulose was digested after 30 days of incubation to coffee exocarps. A medium containing rice husk powder and lactose with $\mathrm{pH} 7.0$ positively affected
\end{abstract}

\section{H. B. Bui $(\bowtie)$}

Department of Biotechnology, Faculty of Chemistry,

Danang University of Technology, The University of Danang,

Danang, Vietnam

e-mail: vantuong_2009@yahoo.com.vn the cellulolytic activity of A1 and A9 strains. Cellulolytic activity of B4 and B7 strains was also most appropriate when the medium contained peptone, $\mathrm{CMC}$, and with a $\mathrm{pH}$ 7.0. Optimal temperature for actinomycetes and bacteria isolate strains was at $25-35{ }^{\circ} \mathrm{C}$.

Conclusion We concluded that the cellulolytic bacteria and actinomycete could be isolated from coffee exocarps which are normally discharged into the environment in coffee-producing areas. These microorganisms could be used to decompose cellulosic wastes, making compost from coffee exocarps, which could be applied in agriculture in Vietnam and other developing countries.

Keywords Actinomycetes - Bacteria - Cellulosedegrading · Cellulolytic · Cellulose - Coffee exocarp · Isolation

\section{Introduction}

The use of microorganisms as catalysts in the biodegradation of organic compounds (cellulose, lignin cellulose) in the natural environment has advanced significantly during the past years (Hesham 2007; Mandels 1975; Opatokun et al. 2011; Pe'rez et al. 2002; Jyotsna et al. 2010). It has been found that large numbers of microorganisms co-exist in almost all natural environments, particularly in soil, water, gastric juices of herbivores, the gut of the earthworm and mulberry caterpillar, and the wood wasp, i.e., (Jyotsna et al. 2010; Anand et al. 2009; Aaron et al. 2011; Atsushi et al. 2009). In recent years, there has been interest in the use of microorganisms to degrade cellulose materials. The search for new and different cellulose-degrading microorganisms has increased, and new species have been isolated from various natural habitats (Jyotsna et al. 2010; Anand 
et al. 2009; Aaron et al. 2011; Alexandre et al. 2008; Atsushi et al. 2009; Sirisena and Manamendra 1995; Hesham 2007; Khwaja et al. 2012). However, no example of cellulolytic activity of coffee exocarp bacteria and actinomycetes has been reported.

Coffee is one of the popular drinks in the world (Hilten 2002). According to estimates, the amount of cultivate worldwide area is nearly 10.3 million hectares, in which Brazil, Vietnam, Columbia, Indonesia, and Ethiopia are the most important producers (Pohlan and Janssens 2012). Vietnam is presently the biggest Robusta coffee producer; for Arabica, Brazil is leader of the world market as it is the biggest producer (Enden and Calvert 2002). In the process of producing coffee, the coffee cherries are dried immediately and later they are harvested through sun drying, solar drying or artificial drying. After being dried and picking of coffee cherries, the cherries are hulled. In this process, the dried outer layer of the cherry, known as the pericarp or exocarp (Fig. 1), is removed mechanically (Enden and Calvert 2002). Countries in the world have used coffee exocarps to produce feed for poultry, growing mushrooms, producing fertilizer, natural fragrance production, and various other products. However, a large amount of coffee exocarps discharged into environment or burnt every year, thus causing considerable environmental pollution and waste in Vietnam. Besides, coffee exocarps in normal conditions are very hard to degrade without the participation of microorganisms. The main objective of this study is to collect bacteria, including actinomycetes from coffee exocarps which were collected from coffee-producing areas in Vietnam after it was discharged into the environment following the production process, and testing cellulolytic activities of all isolates.

\section{Materials and methods}

Sample collection

Fifteen coffee exocarp samples were collected from four coffee-producing areas in Vietnam, each containing $40 \mathrm{~g}$ of coffee exocarps. These samples collected from different places in the same area of production. The samples were collected in sterile boxes and transferred to the laboratory for bacterial isolation.

\section{Experimental setup}

The mineral salt medium (MM) used for enrichment and growth was modified from the one used by Fortnagel and coworkers (1990), and comprised (per liter): $3.5 \mathrm{~g}$ of $\mathrm{Na}_{2} \mathrm{HPO}_{4} .2 \mathrm{H}_{2} \mathrm{O}, 1.0 \mathrm{~g}$ of $\mathrm{KH}_{2} \mathrm{PO}_{4}, 0.5 \mathrm{~g}$ of $\left(\mathrm{NH}_{4}\right)_{2} \mathrm{SO}_{4}$; $0.1 \mathrm{~g}$ of $\mathrm{MgCl}_{2} \cdot 6 \mathrm{H}_{2} \mathrm{O}, 50 \mathrm{mg}$ of $\mathrm{Ca}\left(\mathrm{NO}_{3}\right)_{2} \cdot 4 \mathrm{H}_{2} \mathrm{O}, 1 \mathrm{~mL}$ of vitamin $\mathrm{B} 12$, and $1 \mathrm{~mL}$ of trace salt solution. The final $\mathrm{pH}$ of the medium was 7.2. The trace salt solution contained $0.01 \mathrm{~g} \quad \mathrm{MoO}_{3}, \quad 0.07 \mathrm{~g}$ of $\mathrm{ZnSO}_{4} .5 \mathrm{H}_{2} \mathrm{O}, \quad 0.005 \mathrm{~g}$ of $\mathrm{CuSO}_{4} .5 \mathrm{H}_{2} \mathrm{O}, 0.01 \mathrm{~g}$ of $\mathrm{H}_{3} \mathrm{BO}_{3}, 0.01 \mathrm{~g}$ of $\mathrm{MnSO}_{4} .5 \mathrm{H}_{2} \mathrm{O}$, $0.01 \mathrm{~g}$ of $\mathrm{CoCl}_{2} \cdot 6 \mathrm{H}_{2} \mathrm{O}$, and $0.01 \mathrm{~g}$ of $\mathrm{NiSO}_{4} \cdot 7 \mathrm{H}_{2} \mathrm{O}$ in $100 \mathrm{~mL}$ of water. For enrichment and growth, a mineral salt medium which has been previously described was used with filter paper (Whatman No. 1 filter paper of area $70.541 \mathrm{~cm}^{2}$ ) as the substrate. With coffee exocarp samples from areas of coffee production in Vietnam, enrichment culture was started by mixing $10 \mathrm{~g}$ of the samples to $100 \mathrm{~mL}$ of distilled water and shaking for $1 \mathrm{~h}$ on a rotary shaker at $250 \mathrm{rpm}$ to disperse the samples. Following this, $100 \mathrm{~mL}$ of samples was mixed with $200 \mathrm{~mL}$ of a mineral salt medium supplemented with filter paper as the sole source of carbon and energy, and incubated aerobically at $30{ }^{\circ} \mathrm{C}$ on a rotary shaker at $150 \mathrm{rpm}$ (Fortnagel et al. 1990). Aliquots were transferred weekly from the culture to fresh medium. Subcultures were streaked onto nutrient medium, and incubated aerobically at $30^{\circ} \mathrm{C}$. After incubation at $30{ }^{\circ} \mathrm{C}$, single colonies were transferred onto mineral salt agar mediums containing the above carbon source. Wellgrown pure colonies were picked up and transferred on to mineral salt agar medium, and were stored at $4{ }^{\circ} \mathrm{C}$ until used for next experiments.

Microbial strains that appeared to have cellulosedegrading capacity were selected and isolated. The cellulose agar media which were used for bacterial isolation comprise (per liter): $0.5 \mathrm{~g}$ of $\mathrm{KH}_{2} \mathrm{PO}_{4}, 0.25 \mathrm{~g}$ of $\mathrm{MgSO}_{4}$, $2.0 \mathrm{~g}$ of cellulose, $15 \mathrm{~g}$ of agar, $2 \mathrm{~g}$ of gelatin, and $\mathrm{pH}$ 6.8-7.2 (Pratima et al. 2011). The solid medium, which contained cellulose as a sole source of carbon, carried out for actinomycetes and bacteria. Bacterial isolation comprises $10 \mathrm{~g}$ of $\mathrm{CMC}, 2.5 \mathrm{~g}$ of $\left(\mathrm{NH}_{4}\right)_{2} \mathrm{SO}_{4}, 0.5 \mathrm{~g}$ of yeast extract, $2.7 \mathrm{~g}$ of $\mathrm{KH}_{2} \mathrm{PO}_{4}, 5.3 \mathrm{~g}$ of $\mathrm{Na}_{2} \mathrm{HPO}_{4}, 0.2 \mathrm{~g}$ of $\mathrm{NaCl}, 0.2 \mathrm{~g}$ of $\mathrm{MgSO}_{4} .7 \mathrm{H}_{2} \mathrm{O}, 0.05 \mathrm{~g}$ of $\mathrm{CaCl}_{2}$, and initial pH 7.2-7.4 (Crawford 1983).

Cellulolytic activity was examined by Congo-Red method which has been previously described, and was used for the screening of cellulolytic bacterial and actinomycetes strains (Pratima et al. 2011). To estimate concentration of cellulose degradation by isolated bacteria and actinomycetes, we used the gravimetric determination method of cellulose digestion. The isolated bacterial and actinomycetes strains were grown in the above mineral salt medium with filter paper as the sole source of carbon and energy (Crawford 1983; Pratima et al. 2011). The pH was adjusted to 7.0. The flasks were inoculated with an abundant cell mass from stock cultures. The cultures were incubated at $150 \mathrm{rpm}$ on rotary shaker at $30{ }^{\circ} \mathrm{C}$ for 4 days in $50 \mathrm{~mL}$ Erlenmeyer flasks with $10 \%$ of medium in each flask, and a flask without cell mass was used as controls. Cellulose degradation was calculated by comparing the 
weight loss of the inoculated flasks with that of the control flasks (flask without cell mass) after both samples were dried to a constant weight. The difference between the inoculated flasks and the control flasks was used to estimate the degree of degradation which was expressed as a percentage of the latter.

The identification of the strains has been carried out by standard biological and biochemical characteristics as

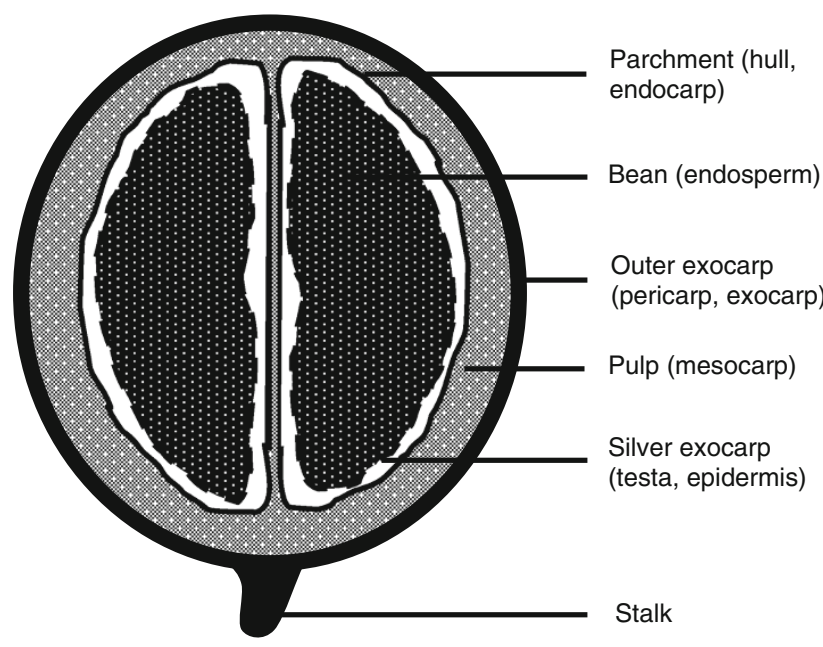

Fig. 1 Schematic representation of cross-section of a coffee cherry (Kuit et al. 2004; Castro and Marraccini 2006) described in Dhanajayan et al. (2010), Acharya et al. (2012), Becker et al. (1964), Brenner et al. (2005), and Reddy et al. (2011).

Determination of the effect of various culturing conditions on cellulolytic activity of isolated actinomycetes and bacterial strains was carried out. For the effect of carbon sources, the isolates were cultured in different carbon sources, such as rice husk powder, glucose, CMC, bagasse powder, and corncob powder. Similarly, to study the effect of nitrogen source, the isolates were cultured on various nitrogen compounds, such as $\left(\mathrm{NH}_{4}\right)_{2} \mathrm{SO}_{4}, \mathrm{NH}_{4} \mathrm{NO}_{3}$, $\mathrm{NaNO}_{3}$, peptone, and urea. For determination of the $\mathrm{pH}$ effect of cellulolytic activity on the isolates, experiments were carried out as described above, using different $\mathrm{pH}$ values $(3.0,3.5,4.0,4.5,5.0$, and 5.5). The temperature used for this study was $20,25,30,35,40$, and $45^{\circ} \mathrm{C}$. Finally, the effect of incubation period on cellulose activity was also studied. The incubation period was $2,3,4,5$, and 6 days for actinomycetes strains, and $24,36,48,60$, and $72 \mathrm{~h}$ for bacterial strains.

\section{Statistical analysis}

Statistical analyses performed by Student's $t$ test, one-way ANOVA test and data were expressed as the averages \pm standard deviation (SD). The averages and SD of the means as the error bars were calculated using Microsoft
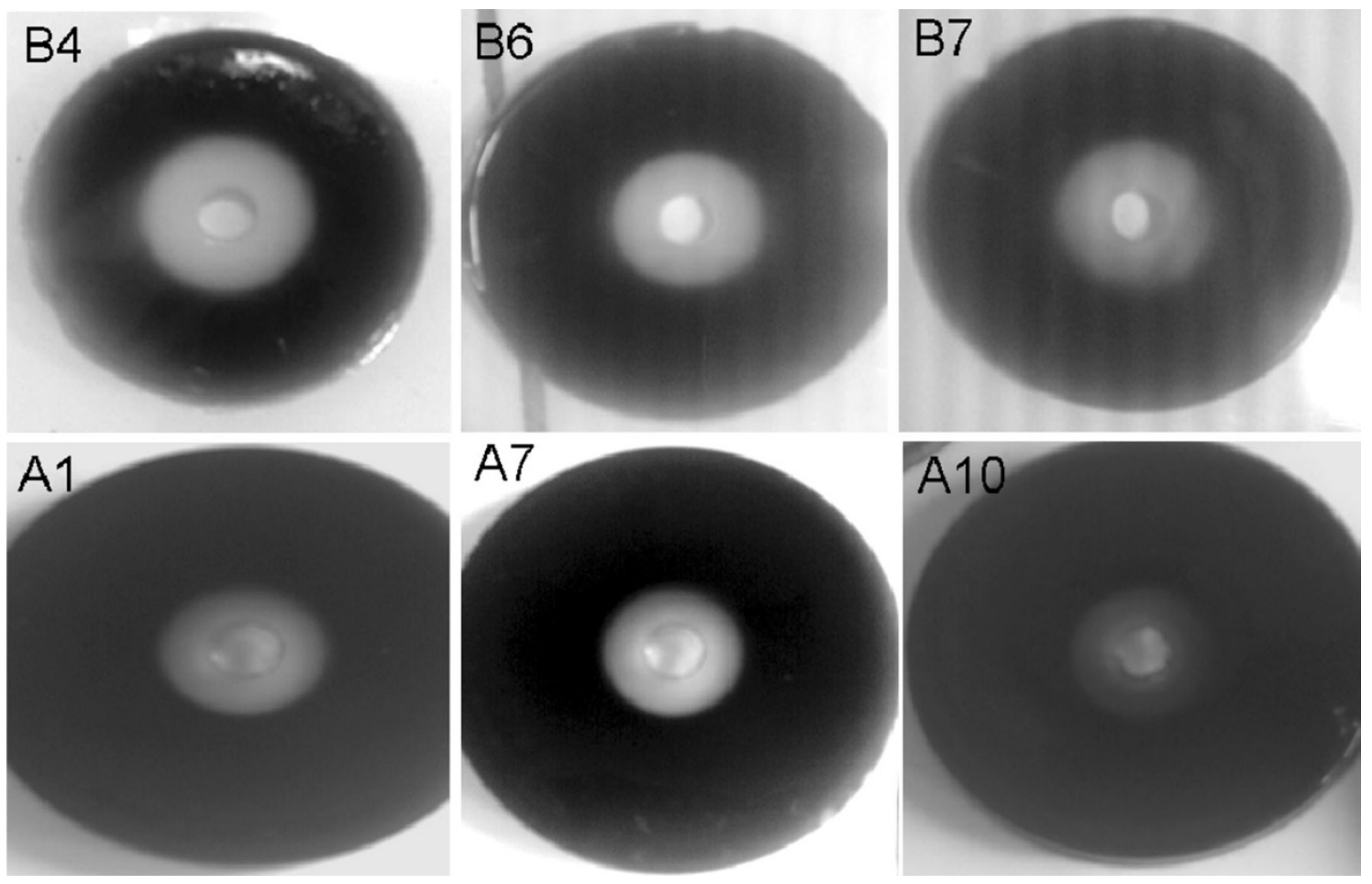

Fig. 2 Cellulolytic activity of isolated strains B4, B6, B7, A1, A7, and A10. Zone of clearance on cellulose Congo Re dagarplates for isolate strains after $48 \mathrm{~h}$ of incubation. The formation of clearing zone around the colonies confirms the secretion of extracellular cellulase 
Excel 2007 (Vista Edition, Microsoft Corporation, USA). Differences were considered to be statistically significant when $P<0.05, P<0.01$, and $P<0.001$. All data were analyzed using the R language on the Windows XP platform (R Development Core Team 2008).

\section{Results and discussion}

In this screening, Congo-Red method was used for screening of bacteria and actinomycetes with cellulolytic activities. Colonies showing discoloration of Congo-Red were taken as positive cellulose-degrading bacterial and actinomycetes colonies. Cellulose degradation potential of isolated bacterial and actinomycetes strains was also qualitatively estimated with the ratio of diameter of clearing zone and colony. The simplicity of this assay makes it useful for screening the cellulolytic capacity of large numbers of these microorganisms. A total of bacterial isolates including actinomycetes isolates were found to be positive on screening media (cellulose Congo-Redagar) producing clear zone (as shown in Fig. 2). Results from cellulolytic activity indicated that out of 38 bacteria and 18 actinomycetes isolated from 15 coffee exocarp samples tested, 13 bacterial strains $(>34 \%)$ and 10 actinomycetes strains $(>56 \%)$ showed enzymatic degradation of cellulose (Table 1). From the results in Table 1, we found that actinomycetes are more abundant than bacteria. However, cellulolytic activity by actinomycetes was much lower than the isolated bacteria.

Also nine isolated bacterial strains and six isolated actinomycetes strains, which scored negative on the cellulose-degrading test, after tested 10 days of incubation, digested in that time over 80 and $50 \%$, respectively, of the supplied cellulose when grown in shaken flasks, respectively. The submerged cultures allow a faster metabolism, probably due to better contact of cells with the cellulose fibers in the liquid medium. It was confirmed using microscopic examination that the strains B4, B7, and A1, which digested over 90 and $80 \%$ of the cellulose after 10 days of incubation, respectively, were completely lysed in that time. By comparison, cellulose-degrading capacity of the isolated microorganism strains was high (>96\%) with filter paper; however, for coffee exocarps were lower, and only about $37 \%$ of the cellulose was digested after 30 days. Cellulose biodegradation of coffee exocarps was observed with nine bacterial strains and four actinomycetes strains. These results are in consistent with previous reports (Godden et al. 1992; Crawford 1983); actinomycetes thus are important agents of lignocellulose degradation, although their ability to degrade cellulose and lignin is not as high as that of fungi. Nonetheless, it is possible to isolate microorganisms directly from coffee exocarps to aid
Table 1 Screening of bacteria and actinomycetes strains with cellulolytic activity and a percentage of cellulose biodegradation

\begin{tabular}{|c|c|c|c|c|c|}
\hline \multirow[t]{2}{*}{$\begin{array}{l}\text { Strain } \\
\text { numbers }\end{array}$} & \multicolumn{3}{|c|}{$\begin{array}{l}\text { Congo-Red test } \\
\text { result by the } \\
\text { following day of } \\
\text { incubation }\end{array}$} & \multirow{2}{*}{$\begin{array}{l}\% \text { cellulose } \\
\text { digestion } \\
\text { (10 days } \\
\text { fermentation to } \\
\text { filter paper) }\end{array}$} & \multirow[t]{2}{*}{$\begin{array}{l}\% \text { cellulose } \\
\text { digestion ( } 30 \text { days } \\
\text { fermentation to } \\
\text { coffee exocarps) }\end{array}$} \\
\hline & 4 & 7 & 10 & & \\
\hline B4 & + & ++ & +++ & $92.1(0.21)$ & $37.6(0.20)$ \\
\hline B6 & + & + & +++ & $87.0(0.05)$ & $31.3(0.25)$ \\
\hline B7 & + & ++ & +++ & $96.2(0.02)$ & $36.0(0.36)$ \\
\hline B12 & + & ++ & +++ & $83.8(0.50)$ & $30.9(0.17)$ \\
\hline B13 & - & ++ & ++ & NT & NT \\
\hline B15 & + & + & +++ & $81.2(0.14)$ & $28.7(0.20)$ \\
\hline B18 & + & + & +++ & $83.1(0.30)$ & $30.3(0.16)$ \\
\hline B19 & - & + & + & $51.6(0.45)$ & NT \\
\hline B21 & - & + & ++ & $63.9(0.35)$ & NT \\
\hline B24 & - & - & ++ & $75.9(0.45)$ & NT \\
\hline B25 & - & - & ++ & $74.3(0.21)$ & NT \\
\hline B28 & - & + & ++ & NT & NT \\
\hline B29 & + & ++ & +++ & NT & NT \\
\hline B31 & - & + & +++ & $80.2(0.41)$ & $25.6(0.15)$ \\
\hline B32 & - & + & +++ & $81.3(0.58)$ & $20.9(0.37)$ \\
\hline B38 & - & + & +++ & $87.3(0.49)$ & $30.5(0.20)$ \\
\hline A1 & + & ++ & +++ & $88.0(0.72)$ & $27.8(0.53)$ \\
\hline A9 & + & ++ & ++ & $76.6(0.58)$ & $25.25(0.15)$ \\
\hline A10 & - & + & ++ & $68.9(0.51)$ & $21.6(1.00)$ \\
\hline A12 & - & - & + & $28.9(0.14)$ & NT \\
\hline A13 & - & + & ++ & $51.1(0.84)$ & NT \\
\hline A14 & - & - & + & $48.9(0.02)$ & NT \\
\hline A 15 & - & - & + & $24.4(0.22)$ & NT \\
\hline A16 & - & - & + & $45.6(0.01)$ & NT \\
\hline A17 & - & + & ++ & $55.5(0.07)$ & NT \\
\hline A18 & - & + & ++ & $68.9(1.35)$ & $20.3(1.00)$ \\
\hline
\end{tabular}

Symbols were mean $(-)$-negative or present; $(+)$-weakly positive; $(++)$-positive; $(+++)$-strongly positive. Values are mean (SD). Shown are representative data from three biological replicate. One-way ANOVA test significance between the isolated strains was performed $(P<0.001)$

$N T$ not tested

biodegradation of coffee exocarps in the areas of coffee processing.

To identify the isolated strains, we used the technique and microscopic examination, and biochemical test. Considering to previously report (Acharya et al. 2012; Dhanajayan et al. 2010; Reddy et al. 2011), the isolates were identified as belonging to member of the Genus Streptomyces sp., Actinomycetes sp., Clostridium sp., and Bacillus sp.; whereas A1, A9, B4, and B7 strain were identified as Steptomyces sp., Bacillus sp., respectively (Table 2). All the four isolates were found to be Gram positive. The result is in consistent with previous reports (Tuomela et al. 2000) 
Table 2 Biochemical identification of the isolated actinomycetes and bacterial strains

\begin{tabular}{llllll}
\hline No. & Test & A1 & A9 & B4 & B7 \\
\hline 1 & Gram's staining & + & + & + & + \\
2 & Indole test & - & + & - & - \\
3 & Methyl red test & + & + & + & + \\
4 & Voges Proskauer test & - & + & + & + \\
5 & H2S production test & - & + & + & + \\
6 & Catalase test & + & + & + & + \\
7 & Oxidase test & - & + & + & + \\
8 & Glucose fermentation test & - & - & + & + \\
11 & Urea hydrolysis test & + & + & + & + \\
12 & Citrate utilization test & + & + & + & - \\
13 & Nitrate reduction test & + & + & - & - \\
14 & Adonitol test & - & - & + & + \\
15 & Sorbitol test & - & - & - & ND \\
16 & Dextrose test & + & + & ND & ND \\
17 & Raffinose test & - & - & - & - \\
18 & Sucrose test & + & ND & - & - \\
19 & Xylose test & - & ND & - & - \\
20 & Lactose test & + & + & + & + \\
21 & Maltose test & + & + & - & - \\
20 & Mannitol test & + & + & - & ND \\
21 & Fructose test & Inositol test & + & - & - \\
22 & ND & ND & - \\
\hline
\end{tabular}

Symbols were mean (-) —negative or present; (+)—weakly positive; $(++)$-positive; $(+++)$-strongly positive; symbols of Gram's staining were mean $(-)$ - Gram negative, $(+)$ - Gram positive

$N D$ not data available

that actinomycetes and a group of Gram-positive bacteria decomposed organic substrates in compost, such as proteins and cellulose, and in solubilizing lignin.

As shown in Table 1, the cellulolytic activity of A1, A9, B4, and B7 strains appeared more predominant than other isolates when coffee exocarps and filter paper were added. So, it was decided to use these actinomycetes and bacterial isolates for further studies. It is generally known that microorganisms continually sense environmental conditions to adapt their growth and development, and enzymes synthesis (cellulase, protease) in particular is greatly influenced by many factors, of which the most important is culture conditions. We studied some of the environmental factors influencing cellulolytic activity of the isolated bacteria and actinomycetes strains.

First, we researched the effect of the various carbon and nitrogen sources to cellulolytic activity of the four isolates (A1, A9, B4, and B7 strain). It has been shown that in favorable environmental conditions, each species of other microorganisms will use one or more suitable carbon sources for their growth and enzyme synthesis. As results
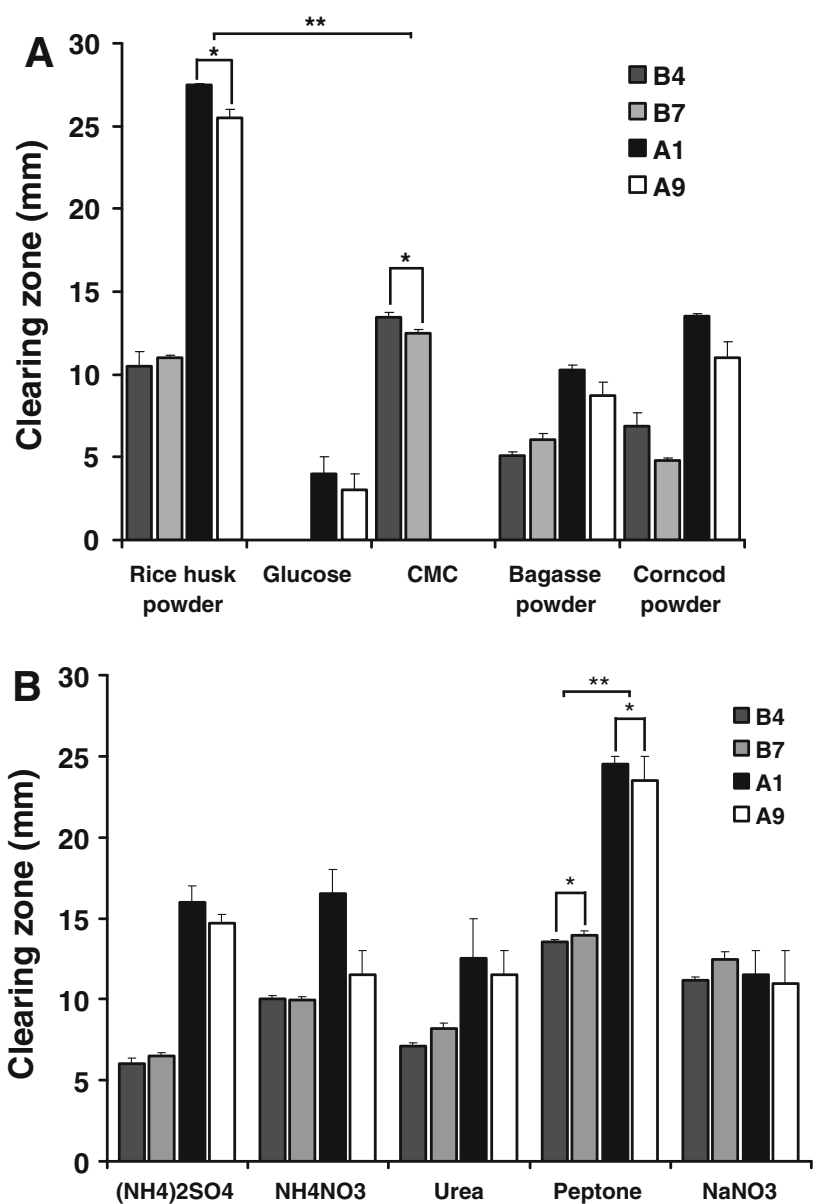

Fig. 3 Cellulolytic activity of the isolated actinomycetes and bacterial strains affected by $\mathrm{C}$ and $\mathrm{N}$ sources a The effect of carbon sources. The actinomycetes and bacterial strains cultured on medium with various carbon sources before examined in the clear zone. Data shown are average \pm SD of three biological replica. Student's $t$ test significance between A1 and A9 strains, or B4 and B7 strains, or between pairs indicated by brackets was performed ${ }^{*} P<0.05$; $\left.{ }^{* *} P<0.01\right)$. $\mathbf{b}$ The effect of nitrogen compounds on the activation of enzymes in the biosynthesizing ability of the isolates. Rice husk powder was used as the carbon source and the isolates cultured in different $\mathrm{N}$ compounds. Clearing zone $(\mathrm{mm})$ was determined after appropriate incubation time. Data shown are average \pm SD of three biological replica. Student's $t$ test significance between A1 and A9 strains, or B4 and B7 strains, or between pairs is indicated by brackets $\left({ }^{*} P<0.05 ;{ }^{* *} P<0.01\right)$

show in Fig. 2 that, when the isolates were cultured in various $\mathrm{C}$ and $\mathrm{N}$ compounds, this led to an obvious induction in the cellulolytic activity. Potential $\mathrm{C}$ sources for actinomycetes and bacterial strains (A1, A9, B4 and B7) were rice husk powder and $\mathrm{CMC}$ with the clearing zone in a range of $25.5 \pm 0.50-27.5 \pm 0.05 \mathrm{~mm}$ (mean $\pm \mathrm{SD}$ ), and $12.5 \pm 0.20-13.46 \pm 0.25 \mathrm{~mm}$, respectively, whereas potential $\mathrm{N}$ source for broth was peptone (Fig. 3a, b). The present results showed lower cellulolytic activity with inorganic nitrogen sources which are consistent with previous studies (Acharya and Chaudhary 2012; 

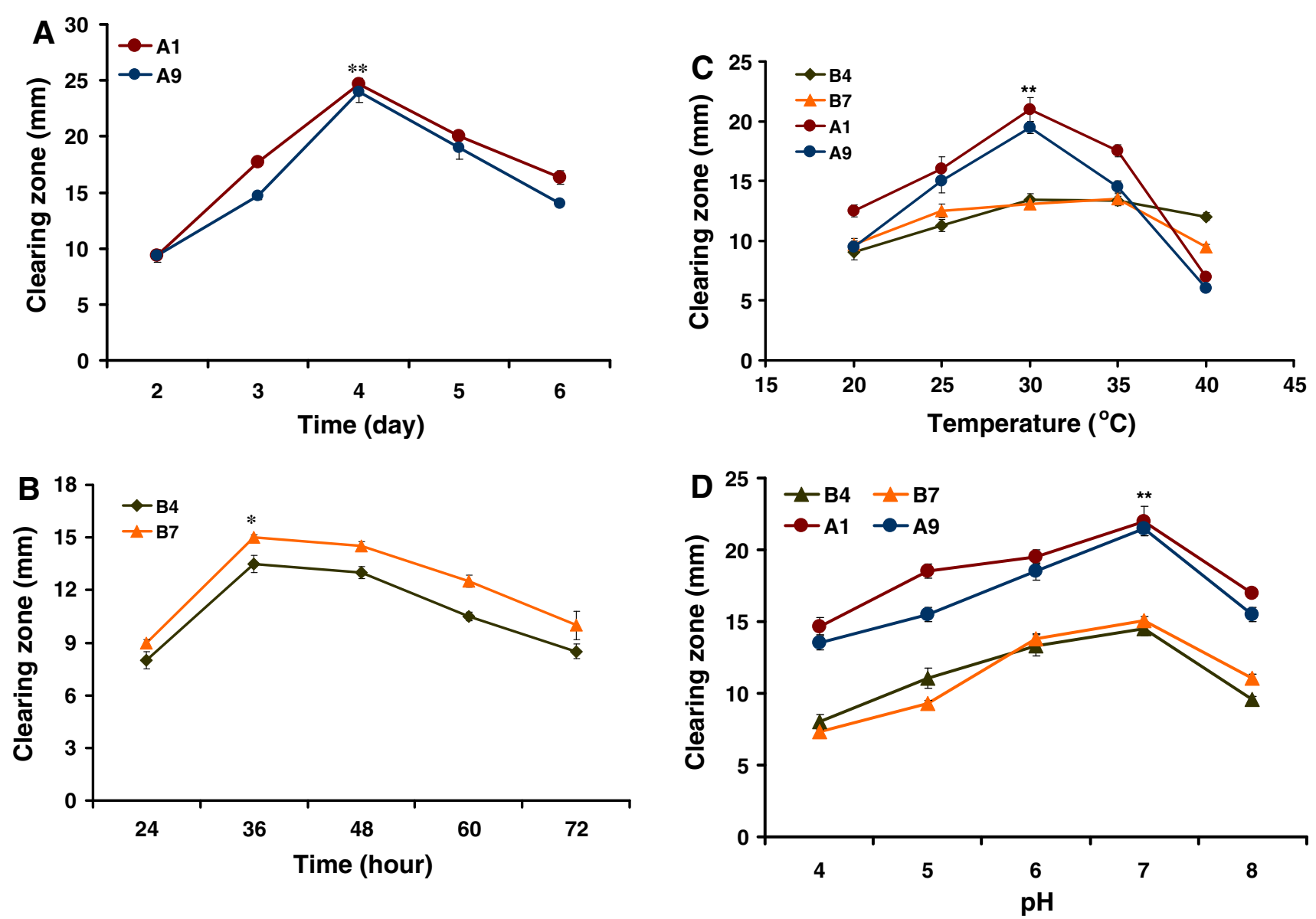

Fig. 4 The effect of the different factors on cellulolytic activity of actinomycetes and bacteria isolated strains. a, b The effect of incubation time. The isolates cultured on medium containing rice husk powder and peptone at various incubation times before clearing zone $(\mathrm{mm})$ was determined. Error bars represent SD of three biological replica. Student's $t$ test significance between incubation time $\left({ }^{*} P<0.05 ;{ }^{* *} P<0.01\right)$. c The effect of the temperature on

cellulolytic activity of the isolates. Cellulolytic activity of the isolates at temperature value was measured. Asterisks represent Student's $t$ test significance between A1 strain and B4 strain $\left({ }^{* *} P<0.01\right)$. d The effect of $\mathrm{pH}$ value. Clearing zone $(\mathrm{mm})$ was measured after the isolates cultured across a range of $\mathrm{pH}$ value. Error bars represent $\mathrm{SD}$ of three biological replica. Asterisks represent Student's $t$ test significance between A1 strain and B4 strain $\left({ }^{* *} P<0.01\right)$

Ray et al. 2007). These data were in accordance with the previous results (Ray et al. 2007) that organic nitrogen sources were more suitable for optimizing the cellulase production by Bacillus subtilis and Bacillus circulans than inorganic sources. On the contrary, Spiridonov and Wilson (1998) found that $\mathrm{NH}_{4}{ }^{+}$compounds were the most favorable nitrogen sources for cellulase synthesis (Spiridonov and Wilson 1998). Study of Acharya and Chaudhary (2012) also showed that cellulolytic activity by both the isolates (Bacillus licheniformis MVS1 and Bacillus sp. MVS3 isolated from Indian Hot Spring) was detected after 60-h incubation period using wheat and rice straw (Acharya and Chaudhary 2012). These results suggest that the wastes from rice (rice husk, rice straw) may use as an optimal carbon source for actinomycetes and bacterial strains.

To determine the optimal incubation period for the biosynthesis of cellulase, we cultured the isolates on the

rice husk powder and CMC may be used as medium for actinomycetes and bacteria strains, respectively, whereas the nitrogen source was peptone. The results showed that the respective cellulolytic activity of actinomycetes strains increased gradually at 2-3 days of culture and with a peak at 3 days of culture in A9 and A4 isolates, namely $24.0 \pm$ $1.00 \mathrm{~mm}$ and $24.8 \pm 0.53 \mathrm{~mm}$, respectively (Fig. 4a). The cellulolytic activity then decreased gradually after 4-6 days of culture, only $14.0 \pm 0.22-15.3 \pm 0.58 \mathrm{~mm}$. Similarly, for bacteria, the cellulolytic activity also markedly increased with a peak at $36 \mathrm{~h}$ of culture, at $13.5 \pm 0.5-15.0 \pm 0.15 \mathrm{~mm}$, then reduced to the prolonged incubation time (Fig. 4b). It is generally known that the culture time is prolonged; the growth potential as well as cellulase biosynthesis of actinomycetes and bacterial strains was reduced, because culture medium becomes unfavorable with reduced nutrient sources and accumulated exchanging compounds, therefore, affecting cellulolytic 
activity of the isolates. Correlating with previous report, $B$. subtilis showed highest zone of hydrolysis as $21 \mathrm{~mm}$ in 8 days at optimal cellulose basal medium (Acharya et al. 2012)

Correlating the temperature to research the impact of temperature on the cellulolytic activity, we examined culturing actinomycetes and bacterial strains in a suitable medium at a range of temperature values. As shown in Fig. 3c, the cellulolytic activity of actinomycetes increased markedly at $20-25{ }^{\circ} \mathrm{C}$ and elevated to a peak at $30{ }^{\circ} \mathrm{C}$ after culture (from $19.5 \pm 0.50$ to $21.0 \pm 1.00 \mathrm{~mm}$ ), and then transiently decreased when the temperatures climbed to $40{ }^{\circ} \mathrm{C}$ (only $6.0 \pm 0.02-7.0 \pm 0.10 \mathrm{~mm}$ ). These results suggest that cellulolytic activity of A1 and A9 actinomycetes was at a temperature of $25-35{ }^{\circ} \mathrm{C}$. Correlating to cellulolytic activity of isolate bacteria, the result also shown that the potential temperature was at $30-35^{\circ} \mathrm{C}$. The optimum temperature for $\mathrm{B} 4$ and $\mathrm{B} 7$ is 30 and $35^{\circ} \mathrm{C}$ with a clearing zone of $13.4 \pm 0.50$ and $13.5 \pm 0.43 \mathrm{~mm}$, respectively. With the range of temperature value lower than $20^{\circ} \mathrm{C}$ or higher than $40{ }^{\circ} \mathrm{C}$, the cellulolytic activity declined. We compared to previously studies that the cellulolytic activity of B. subtilis was maximum at $50-60{ }^{\circ} \mathrm{C}$ (Acharya et al. 2012; Mohagheghi et al. 1986). Apparently in this study, cellulase activity of B. subtilis was optimum at $50{ }^{\circ} \mathrm{C}$. Actinomycetes RK6 strain showed maximum activity at $38{ }^{\circ} \mathrm{C}$ (Kumar et al. 2013). However, in the present study, the isolates have optimal temperature at $30-35{ }^{\circ} \mathrm{C}$, less than that stated by previous researchers.

$\mathrm{pH}$ is also one of the most important parameters essential for the success of activity of synthetic enzyme. Considering previous reports (Acharya and Chaudhary 2012) to this test, we cultured and isolated across a range of $\mathrm{pH}$ value as described above. Consistent with expectations, cellulolytic activity was found to be maximally effective at a $\mathrm{pH} 7.0$ (Fig. 4d), and decreasingly effective at higher $\mathrm{pH}$ value. Streptomyces sp. and Bacillus sp. strains were optimum at $\mathrm{pH}$ 7.0. These data were appropriate with previous reports that cellulolytic activity of actinomycetes isolated from Areraj region, Bihar also had pH 7.0 (Kumar et al. 2013). Besides, there was decreased production of enzymes at alkaline range of $\mathrm{pH}$ (Acharya and Chaudhary 2012). Most microorganisms grow optimally within a wide $\mathrm{pH}$ range. Immanuel et al. (2006) reported that the cellulolytic enzyme from Cellulomonas sp., Bacillus sp., and Micrococcus sp., isolated from the estuarine coir netting effluents hydrolyzes substrate in the $\mathrm{pH}$ range of 4.0-9.0 (Mohagheghi et al. 1986), with maximum activity at $\mathrm{pH}$ 7.0. On the contrary, Song et al. (1985) observed optimal cellulase production at pH 9.0 by Clostridium acetobutylium (Immanuel et al. 2006; Song et al. 1985). It was also known that these bacteria tolerate higher temperatures and $\mathrm{pH}$ than most fungi and can survive as spores under adverse conditions (Cross 1968).

\section{Conclusions}

It was concluded that a large number of microorganisms can be isolated directly from coffee exocarps in natural environments to aid biodegradation of coffee exocarps at coffee-producing areas in Vietnam and can be used for cellulose biodegradation.

Open Access This article is distributed under the terms of the Creative Commons Attribution License which permits any use, distribution, and reproduction in any medium, provided the original author(s) and the source are credited.

\section{References}

Aaron SA, Jordan M, Adams SM, Suen G, Goodwin LA, Davenport KW, Currie CR, Raffa KF (2011) Cellulose-degrading bacteria associated with the invasive woodwasp Sirex noctilio. Int Soc Microb Ecol J 5:1323-1331

Acharya S, Chaudhary A (2012) Optimization of fermentation conditions for cellulases production by Bacillus licheniformis MVS1 and Bacillus sp. MVS3 isolated from Indian Hot Spring. Braz Arch Biol Technol 55:497-503

Acharya A, Joshi DR, Shrestha K, Bhatta DR (2012) Isolation and screening of thermophilic cellulolytic bacteria from compost piles. Sci World 10:43-46

Alexandre BDM, Lockhart RJ, Cox MJ, Allison HE, McCarthy AJ (2008) Cellulose degradation by micromonosporas recovered from freshwater lakes and classification of these Actinomycetes by DNA gyrase B gene sequencing. Appl Environ Microbiol 74:7080-7084

Anand AAP, Vennison SJ, Sankar SG, Prabhu DIG, Vasan PT, Raghuraman T, Geoffrey CJ, Vendan SE (2009) Isolation and characterization of bacteria from the gut of Bombyx mori that degrade cellulose, xylan, pectin and starch and their impact on digestion. J Insect Sci 10:1-20

Atsushi T, Lio W, Mitsumori M, Minato H (2009) Isolation and identification of cellulose-binding proteins from sheep rumen contents. Appl Environ Microbiol 75:1667-1673

Becker B, Lechevaller MP, Gordon RE, Lechevalier HA (1964) Rapid differentiation between Nocardia and Streptomyces by paper chromatography of whole-cell hydrolysates. Appl Microbiol 12:421-423

Brenner DJ, Krieg N, Staley JR (2005) Bergey's Manual ${ }^{\circledR}$ of systematic bacteriology, vol 2. Springer, New York

Castro RDD, Marraccini P (2006) Cytology, biochemistry and molecular changes during coffee fruit development. Br J Plant Physiol 18:175-199

Crawford JH (1983) Composting of agricultural wastes-a review. Process Biochem 18:14-18

Cross T (1968) Thermophilic actinomycetes. J Appl Bact 31:36-53

Development Core Team R (2008) R: a language and environment for statistical computing. R Foundation for Statistical Computing, Vienna

Dhanajayan V, Selvan N, Dhanapal K (2010) Isolation, characterization, screening and antibiotic sensitivity of actinomycetes from locally (near mcas) collected soil samples. J Biol Sci 10:514-519

Enden JCV, Calvert KC (2002). Review of coffee waste water characteristics and approaches to treatment. http://www.coffee. 20m.com/CoffeeProces-sing. Accessed 18 Aug 2013

Fortnagel P, Harms H, Wittich RM, Krohn S, Meyer H, Sinnwell V, Wilkes H, Francke W (1990) Metabolism of dibenzofuran by 
Pseudomonas sp. strain HH69 and the mixed culture HH27. Appl Environ Microbiol 56:1148-1156

Godden B, Ball AS, Helvenstein P, McCarthy AJ, Penninckx MJ (1992) Towards elucidation of the lignin degradation pathway in actinomycetes. J Gen Microbiol 138:2441-2448

Hesham MA (2007) Enhancement of rice straw composting by lignocellulolytic actinomycete strains. Int J Agric Biol 9:106-109

Hilten J (2002) The best coffee is what is sold at a profit. The Sasi Group (Sheffield) and Mark Newman (Michigan)

Immanuel G, Dhanusha R, Prema P, Palavesam A (2006) Effect of different growth parameters on endoglucanase enzyme activity by bacteria isolated from coir retting effluents of estuarine environment. Int J Env Sci Technol 3:25-34

Jyotsna KP, Vijayalakshmi K, Prasanna ND, Shaheen SK (2010) Isolation, Characterization of Cellulase Producing Lysinibacillus sphaericus MTCC No. 9468 from Gut of Eisenia foetida. Int Q J Life Sci 6:325-327

Khwaja S, Prasad R, Gor SH, Visavadia MD, Soni VK, Hussain MD (2012) Biochemical characterization of thermostable cellulase enzyme from Mesophilic strains of Actinomycete. Afr J Biotechnol 11:10125-10134

Kuit M, Jansen DM, Nguyen VT (2004) Manual for Arabica cultivation. Tan Lam Agricultural Product Joint Stock Company, Quang Tri

Kumar R, Lone SA, Ali S, Pattnaik S, Kumari N, Kumar D, Nehra P, Seenivasan P (2013) Cellulolytic activity of actinomycetes isolated from Areraj region, Bihar. Curr Discov 2:92-96

Mandels M (1975) Microbial sources of cellulases. Biotechnol Bioeng Symp 5:81-105

Mohagheghi A, Grohmann K, Himmel M, Leighton L, Updegraff DM (1986) Isolation and characterization of acidothermus cellulolyticus gem nov., sp. nov., a new genus of thermophilic, acidophilic, cellulolytic bacteria. Int J Syst Bacteriol 36:435-443
Opatokun SA, Kabbashi N, Alam MZ, Salihu A, Abass A, Ruqayyah TLD (2011) Composting of food and yard wastes by locally isolated fungal strains. Afr J Biotechnol 10:18800-18806

Pe'rez J, Muñoz-Dorado J, de la Rubia T, Martínez J (2002) Biodegradation and biological treatments of cellulose, hemicellulose. Int Microbiol 5:53-63

Pohlan HAJ, Janssens MJJ (2012) Growth and production of coffee. Soil, Plant Growth Crop Produc 3:1-11

Pratima G, Samant K, Sahu A (2011) Isolation of cellulose-degrading bacteria and determination of their cellulolytic potential. Int J Microbiol 2012:1-5

Ray AK, Bairagi A, Ghosh KS, Sen SK (2007) Optimization of fermentation conditions for cellulase production by Bacillus subtilis CY5 and Bacillus circulans TP3 isolated from fish gut. Acta Ichthyologica ET Piscatoria 37:47-53

Reddy NG, Ramakrishna DPN, Raja Gopal SV (2011) A morphological, physiological and biochemical studies of marine Streptomyces rochei (MTCC 10109) showing antagonistic activity against selective human pathogenic microorganisms. Asian J Biol Sci 4:1-14

Sirisena DM, Manamendra T (1995) Isolation and characterization of cellulolytic bacteria from decomposing rice straw. J Natn Sci Coun Sri Lanka 23:25-30

Song FL, Forsberg CW, Gibbins LN (1985) Cellulolytic activity of Clostridium acetobutylium. Appl Env Microbiol 50:220-228

Spiridonov NA, Wilson DB (1998) Regulation of biosynthesis of individual cellulases in Thermomonospora fusca. J Bacteriol 180:3529-3532

Tuomela M, Vikman M, Hatakka A, Itävaara M (2000) Biodegradation of lignin in a compost environment: a review. Bioresour Technol 7:169-183 